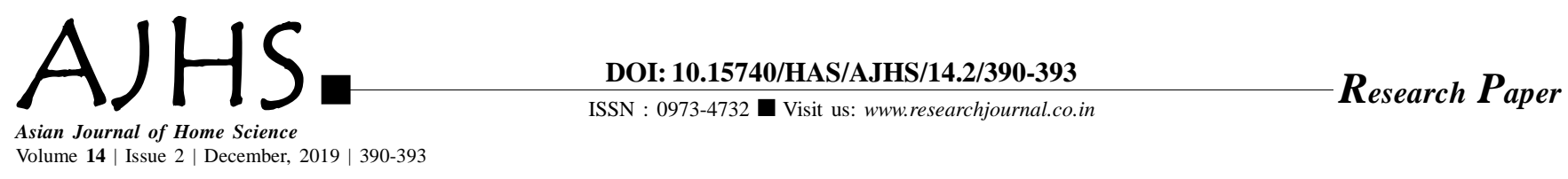

\title{
Development of Rajputi poshaak by using Mandana motif through block printing
}

\author{
Rupal Babel and Renuka Singh Panwar
}

Received: 21.09.2019; Revised: 26.10.2019; Accepted: 10.11.2019

See end of the paper for authors' affiliations

\section{Rupal Babel}

College of Community and

Applied Sciences, Maharana

Pratap University of Agriculture

and Technology, Udaipur

(Rajasthan) India

Email : babelrupa166@gmail.com
ABSTRACT : The present study explores the possibility of development of Rajputi Poshaaks through block printing using Mandana motifs. The objective of present study was to design and construction Rajputi poshaak using adapted Mandana motif through block printing technique. Result of the study revealed that the selected Mandana motifs were falling in the range of 70 per cent to 96 per cent and the selected designed Rajputi poshaak placements were found in the range of 81.33 per cent to 94.66 per cent. The developed Rajputi poshaak through this art can be useful as self-employment project by using them in making different design of Rajputi poshaaks for sale through boutiques or retailers and also a good boost for creativity.

KEY WORDS: Rajputi poshaak, Mandana motif, Block printing

- HOW TO CITE THIS PAPER : Babel, Rupal and Panwar, Renuka Singh (2019). Development of Rajputi poshaak by using Mandana motif through block printing. Asian J. Home Sci., 14 (2) : 390-393, DOI: 10.15740/HAS/AJHS/14.2/390-393. Copyright@ 2019: Hind Agri-Horticultural Society. 